\title{
ЯЗЫКОЗНАНИЕ
}

UDC 811.581

\section{Critical Discourse Analysis of the Image of China in the Russian Version of the Report on the Work of the Government with a Case of Russian Verb Aspects*}

\author{
Yuan Tao \\ Shaanxi Normal University, \\ Chang'an South Road 199, Xian, Shaanxi Province, 710062, People's Republic of China
}

For citation: Yuan Tao. Critical Discourse Analysis of the Image of China in the Russian Version of the Report on the Work of the Government with a Case of Russian Verb Aspects. Vestnik of Saint Petersburg University. Asian and African Studies, 2020, vol. 12, issue 2, pp. 178-193.

https://doi.org/10.21638/spbu13.2020.202

\begin{abstract}
Aspect is an obligatory grammatical category of Russian verbs that consists of both perfective aspect and imperfective aspect as a pair. Based on both self-compiled Chinese-Russian parallel corpora of the Report on the Work of the Government (China) (2008-2017) and comparable corpora of the Report on the Work of the Government (Russia) (2008-2017), this paper presents the intra-lingual, inter-lingual and prosodic analyses of the image of China reflected in the Russian version of the Report on the Work of the Government (China): 1) image of China is created by comparing the verb frequency of two aspects in translational corpora and comparable corpora and analyzing the modal meaning and interpersonal function of Russian verbs; 2 ) ideology in the Russian version is discussed by comparing "V+了 1 " structures in source texts with its counterparts (long passive participles or imperfective aspect) in target texts; 3) main concerns of Chinese government in the past decade are illustrated by focusing on semantic prosodies of collocates (its types and distributions) with high-frequency imperfective verbs in target texts. It concludes that the image of China in translational texts is populist, flexible, responsible and concerned over its national welfare and people's livelihood.
\end{abstract}

Keywords: critical discourse analysis, verb aspects, modals, language and government image.

* We are obliged to The China National Foundation for Social Sciences for their support (Grant number: 16WZS011).

Abbreviations in the paper: RVRC - Russian version of the Report on the Work of the Government (China); R-Report - Report on the Work of the Government (Russia); CL - critical linguistics; TT - target texts; ST - source texts.

() Санкт-Петербургский государственный университет, 2020 


\section{Introduction}

"Critical Discourse Analysis (CDA), as one possible approach to analyzing discourse, focuses on the relationship between language, power, and ideology, i.e., an interdisciplinary approach to the study of discourse that views language as a social practice" [1]. CDA is also a process of "denaturalizing" discourse: by means of analyzing linguistic forms in a discourse, the hidden nexuses among language, power, and ideology may be exposed; how rulers of a country use language to control ideology and safeguard their power may be disclosed [2].

CDA originated from critical linguistics (CL). Since its inception, CL has offered a new perspective on the study of discourse and language for discourse is not only a reflection of social reality but is also a key component of social practice whereby people can understand and explain social behavior through language and discourse.

CDA has been widely applied to a variety of discourse types and it deepens people's understanding of nexus between language and society. In academia, great attention has been paid to people's primary concerns over politics reflected in CDA and the unique lens through which to look at social phenomena. However, due to the small size of texts and its limited representativeness in the traditional CDA research paradigm, a number of researchers have criticized its lack of systematicity and objectivity in interpreting discourse; moreover, they have begun to doubt the standards of careful, rigorous and systematic analysis applied in CDA. Furthermore, they have begun to question the validity and fairness of certain analysts attempting to prove their points through CDA for their analyses fell into the circular reasoning [3-6].

Stubbs and Gerbig and Hardt-Mautner, among many opponents of CDA, have tried to combine corpus linguistics with CDA to increase representativeness of texts [7-8]. A good case in point is Stubbs' Text and Corpus Analysis: Computer-assisted Studies of Language and Culture in which he applied corpus linguistics tools to reveal ideology hidden in texts [9]. Since then many researchers have confirmed the feasibility of combining corpus linguistics with CDA and proposed new theoretical perspectives [10-14]. A recent example is Vessey who outlined how corpus-assisted discourse studies approach can add useful dimensions to studies of language ideology with examples from a larger comparative study of French and English language ideologies in corpora of Canadian newspapers [15].

"CDA approach to a government's image through translations will involve ideology, i.e., ideological factors in translated versions. Translation researchers have focused on this issue since 1980's" [16, p.215]. André Lefevere once pointed out that "translators or re-writers adapt, manipulate the originals they work with to some extent, usually to make them fit in with the dominant, or one of the dominant ideological and poetological currents of their time" [17]. "Ideology in translation refers to translators' or interpreters' underlying ideas and interpretation system in their work" [18, p. 123]. Therefore, "translating behavior is likely to be influenced and even controlled by translators' ideology and literature outlook or by existing political order, thereby resulting in the loss of the stylistic tone and originality of the source texts" [19]. "The recent years have seen the claim of corpus-based approach to probing into the ideology in translation and the concept of corpus-based critical translatology" [20].

So far, we believe that corpus-based CDA can be performed to resolve ideological issues in both translational and non-translational texts. This paper is an attempt to understand how the Chinese government is portrayed in the Russian version of the Report on 
the Work of the Government (China) (2008-2017) (hereafter the R-Report) by focusing on the modality and ideology in the translational texts.

\section{Literature Review}

As mentioned in the introduction, Stubbs and Gerbig combined corpus linguistics and critical discourse analysis in 1993 [21]. Since then, interface studies have been carried out at the theoretic level [22-24] and empirical level. For the latter, on the English version of the Report (2000-2009), Zhu Xiao-min investigated the distribution of WE and its Chinese equivalents (我們) and found WE outnumbers its Chinese equivalents, and underlying ideological factors are explored [25]. Tang Li-ping , on the basis of China-related data from such prestigious papers in the US as The New York Times, Washington Post, and Los Angeles Times (1 September 2008 - 31 December 2010), investigated how such papers constructed the image of China implicitly from the perspectives of evaluative prosody and semantic prosody [26]. Qian Yu-fang and Tian Hai-long listed the key words and word clusters in their corpus of the Report (1999-2008) and revealed the role of the Report as institutional talk in promoting social reform [27]. Shao Bin and Hui Zhi-ming focused on Western media's interpretation, evaluation, and discourse construction of "China Dream" through concordance lines and collocation groups in their corpus with data from Lexis Nexis News database [28]. In the theoretical framework of "extended units of meaning" [29-30], Hu Jiang conducted a CDA of Western media's China-related military reports and found the media's attitudes towards China to be mainly negative and unfavorable [31]. However such interface studies have been conducted unanimously in English and Chinese, which has not been the case in Russian and Chinese.

This paper aims to fill this gap by studying the image of China in the Russian version of the Report (China) (hereafter RVRC) with focus on Russian verb aspects. The following reasons motivate the choice to focus on aspect: 1) there are verb aspects in both Russian and Chinese and much research has been done in both Russian [32-33] and Chinese [3437]. "Verb aspect is an obligatory grammatical category in Russian" [38], i.e., each verb has either perfective aspect or imperfective aspect. Aspects are pervasive in both translational texts and non-translational texts; 2) Modality refers to the indeterminacy between the positive and negative poles, which interpersonally construct the semantic region of uncertainty that lies between yes and no. Russian verb aspects are rich in functional and modal meanings by which we can reveal ideological factors hidden in institutional discourses (e.g. the Report), and the image of China in RVRC can be achieved likewise.

So far, research on Russian verb aspect has been very detailed: Bondarko studied them in the framework of functional grammar [32]. Shelyakin pointed out that "modalityaspects association" can be realized with some tense-aspect forms of Russian verbs, or infinitives, or imperatives, or subjunctive forms of Russian verbs [33]. Zhang Jia-hua analyzed the functional and semantic category of Russian verbs [38]. Yang Ming-tian (2000) focused on the subjective modal meaning of both perfective and imperfective verbs [39]. Deng Ying studied the subjective modal meaning of Russian verbs on given occasions and she also studied the presupposition meaning of aspects of Russian verbs from the perspectives of pragmatics or cognitive linguistics [40].

At the core of the present paper is the notion that, through translation, the image of the government is constructed differently across different countries. Russia is one of the 
superpowers and also one of the important neighbors and strategic partners of China. With the introduction of the Belt and Road Initiative, many researchers have conducted research on China image in Russia [41-47]. However, their research has been done from historical, philosophical, cultural and immigration perspectives. There is scant research on the image of China through the analysis of institutional discourse in Russian to the best knowledge of author of this paper.

Literature review mentioned above indicates that a further interface study of China image reflected in Russian translation is needed in terms of corpus-based CDA and Russian verb aspects. For CDA, two questions are raised: what are the linguistic features in RVRC compared with non-translational texts and source texts? What are the ideological factors that underlie such linguistic features? For Russian verb aspects, three questions are raised: how many modal meanings do Russian verbs (both perfective and imperfective) have? What are the high-frequency verbs (and their aspects) in the RVRC? What are the ideological features reflected by those verbs (their collocates)?

\section{Methodology}

\subsection{Database}

Institutional discourse is the primary concern in CDA. Data in the current research are from two reports: The Report on the Work of the Government (China) (2008-2017) (the Report) and Отчет в Госдуме (Russia) (2008-2017) (hereafter R-Report). Ten years of the Report and their Russian versions constitute parallel corpora while 10-year R-reports, comparable corpora with each year's report being a separate corpus respectively. Annotations have been done in terms of meta-texts, part of speech and verb aspects. Software ICTCLAS is employed to segment Chinese words, which is complemented by manual check. Details of corpora are in Table 1.

Table 1. Details of the Corpora

\begin{tabular}{|c|c|c|c|c|c|}
\hline \multirow{2}{*}{$\begin{array}{c}\text { Reports } \\
(2008-2017)\end{array}$} & \multicolumn{3}{|c|}{ Parallel Corpora } & \multicolumn{2}{|c|}{ Comparable Corpora } \\
\hline & Chinese words & Russian words & Samples & Russian words & Samples \\
\hline & 198,100 & 129,526 & 10 & 82,857 & 10 \\
\hline
\end{tabular}

Table 1 shows that there are slightly more Russian words in parallel corpora than in comparable corpora but the difference is small. Moreover, years of the reports are the same. In this way, we can make the data elicited from these corpora comparable.

\subsection{Research procedure}

"Aspect in Russian is also a functional-semantic category referring to movement features and distribution features of an action. Such features can be realized through morphology, word formation, lexical-semantic or syntactical devices" [40, p.47]. Usually, a Russian verb consists of perfective and imperfective that constitute a pair of aspects (видовая пара). Each aspect has its constant aspect meaning and variant aspect mean- 
ing $^{1}$. Verb aspects in translational texts may be different from their counterparts in nontranslational texts or source texts. Collocates of high-frequency verbs (their aspects) in TT demonstrate evaluative prosodies.

This paper will:

1) numerate, then compare Russian verbs (two aspects) in RVRC and R-reports and try to disclose ideological meanings hidden in different aspects with the help of modal connotations of Russian verb aspects. Meanwhile, aspects of highfrequency verbs will be discussed to reveal social distance and power relationships between speakers and listeners;

2) talk about the equivalence of the verb aspects in TT to the annotated verb aspects in ST in order to expose the ideological meaning embodied in aspect choices in the translation process;

3) extract high-frequency verbs and their collocates in TT so as to find China's concerns, outline the semantic framework in China's propaganda in Russia and disclose the ideological denotation.

\section{Intra-lingual comparison of aspects in two Reports}

As mentioned above, we have annotated Russian verbs in both RVRC and R-reports. With ParaConc, we figured out the distributions of two aspects in two corpora as shown in Table 2 and Figure 1 respectively.

Table 2. Aspects distribution in two corpora

\begin{tabular}{ccccc}
\hline \multirow{2}{*}{ Years } & \multicolumn{2}{c}{ RVRC } & \multicolumn{2}{c}{ R-report } \\
\cline { 2 - 5 } & imperfective & perfective & imperfective & perfective \\
\hline 2008 & 689 & 256 & 256 & 423 \\
\hline 2009 & 760 & 324 & 245 & 368 \\
\hline 2010 & 458 & 231 & 232 & 411 \\
\hline 2011 & 781 & 381 & 228 & 378 \\
\hline 2012 & 766 & 242 & 229 & 344 \\
\hline 2013 & 484 & 242 & 305 & 425 \\
\hline 2014 & 498 & 251 & 317 & 432 \\
\hline 2015 & 615 & 288 & 218 & 376 \\
\hline 2016 & 587 & 308 & 352 & 363 \\
\hline 2017 & 724 & 277 & 287 & 423 \\
\hline Total & 6362 & 2800 & 2669 & 3943 \\
\hline
\end{tabular}

${ }^{1}$ Constant aspect meaning refers to the default meaning and function of a verb aspect while variant aspect meaning refers to the meaning of verb aspect in certain situations, for example, a perfective verb may have different meanings in the past form, imperative form or in an indicative mood respectively. 


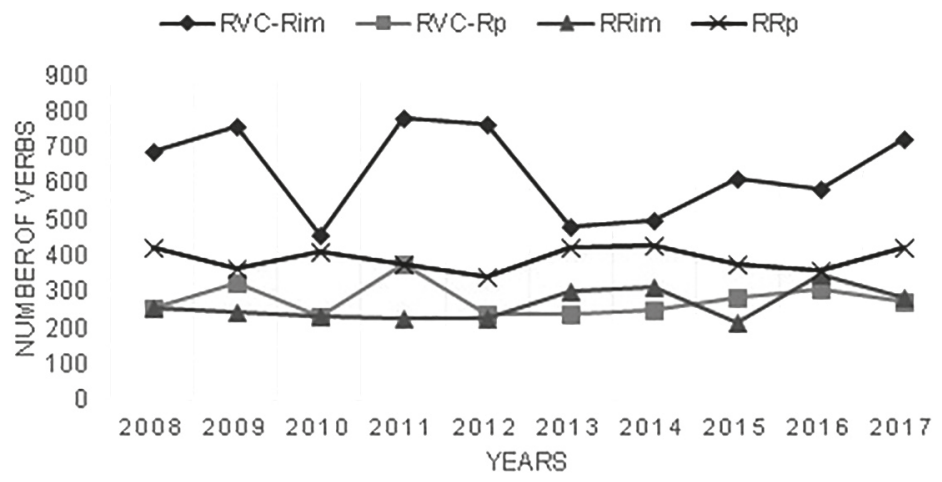

Fig. 1. Aspects distribution in two corpora

RVC-Rim = imperfective verbs in RVRC; RVC-Rp = perfective verbs in RVRC; RRim = imperfective verbs in the R-reports; RRp = perfective verbs in the R-reports

Figure 1 shows clearly that imperfective verbs (the former) outnumber perfective verbs (the latter) in RVRC, especially in years 2009, 2011, 2012 and 2017. The former is 2-3 times the latter; however, perfective verbs are more than imperfective ones in the Rreports but the difference is small and they are nearly the same in 2016.

In addition, imperfective verbs in RVRC exceed both perfective verbs and imperfective verbs in the R-reports. Meanwhile, curve for it (RVC-Rim) fluctuates while the other three curves are nearly flat, which indicates that RVC-Rims are striking and will be our research focus.

"The action a Russian imperfective verb indicates is unlimited and has the feature of completeness" [38]. By analyzing an imperfective verb in RVRC, we may know its modal meanings and ideological characteristics in RVRC.

As usual, the Report on the Work of the Government (China) consists of four parts: Review of the work in the past year, major tasks of the government for this year, self-construction of the government itself, and diplomacy and international affairs. Through observation, most imperfective verbs occur in the second and third parts, for example:

（1）做好今年政府工作，要把握好以下三點...

第三，培育和催生經濟社會發展新動力。當前經濟增長的傳統動力減 弱, 必須加大結構性改革力度, 加快實施創新驅動發展戰略，改造傳統 引擎，打造新引擎。

(1) zuòhăo jīnnián zhèngfǔ gōngzuò, yào băwòhăo y̌xxià sāndiăn... dìsān, péiyù hé cuīshēng jīngjì shèhuì fāzhăn xīndònglì. dāngqián jīngjì zēngzhăng de chuántǒng dònglì jiănruòbìxū jiādà jiégòuxìng găigé lìdù jiākuài shíshī chuàngxīn qūdòng fāzhăn zhànluè, găizào chuántǒng yǐnqíng, dăzào xīny̌nquíng.

B-третьих, культивировать новые движущие силы социально-экономического развития (НСВ), ускорять их рост. Сейчас, когда традиционные НСВ слабеют, необходимо повышать динамичность структурных реформ, ускорять осуществление стратегии инновационного развития, реконструировать старые и создавать новые двигатели прогресса. 
Example 1 is in the second part of the Report. In this example, there are five verbs. Exсерt for реконструировать that can be either perfective or imperfective, the other four are imperfective. Judging by the modal meanings in general, Russian imperfective verbs can be categorized as those denoting concrete process (Group A) and those denoting infinite recursive process (Group B). Imperfective verbs denoting intention as a subcategory in Group A can be used to describe speakers' intention and desire in the process of an action. Imperfective verbs in Group B can be used to describe a regular action and to embody obligation and responsibility. Imperfective verbs in Group B also indicate that speakers have confidence in fulfilling an action. Therefore, analyses of China image implied in imperfective verbs can be done from two dimensions:

1) obligation and responsibility

Such phrases as “加大結構性改革” (to intensify structural reform) and “加快... 戰 略” (to boost efforts to implement strategies of...) demonstrate China's obligation and responsibility. Their Russian equivalents are imperfective verbs, indicating that Chinese government is the bearer of public welfare and interests and the government is ready to shoulder a variety of responsibilities in politics, law and administration, economy development and reform promotion. With the help of imperfective verbs, RVRC presents Russian-speaking readers with an image of a responsible government who cares most its people's welfare and interests;

2) desire and intention

Example 1 shows that China has decided to develop and progress further by "innovating the traditional engines", a desire and intention realized through imperfective verbs that are embedded in a syntactical pattern " $v+$ complement". This pattern demonstrates that China has a clear aim to embrace the future and has the bravery to innovate. Such pattern is brief and economical and fits the economy principle of language, which implies that China has determined to be pragmatic, to lower the cost and improve the efficiency in its administration.

As for the sentence patterns, there are a lot of "infinitive sentences" ("to + v sentences") in which imperfective verbs are embedded. In RVRC, this pattern is special and in real sense it is a complex structure denoting future without будем (=we shall/will). More examples follow:

（2）第二，保持經濟運行處在合理區間。

(2) dìer, băochí jīngjì yùnxíng chùzài hélǐ qūjiān.

Во-вторых, удерживать функционирование экономики в разумном пространстве.

(= Во-вторых, будем удерживать функционирование экономики в разумном пространстве.)

（3）...由先證後照改為先照後證，由企業年檢制度改為年報公示制度...

(3) ...yóu xiānzhènghòuzhào gǎiwéi xiānzhàohòuzhèng, yóu qǐyè niánjiăn zhìdù gǎiwéi niánbào gōngshì zhìdù...

...вводить порядок выдачи патента на право хозяйствования до получения административного разрешения, вместо того чтобы выдавать патент только после получения разрешения; внедрять режим публичного информирования через пред- 
ставляемые предприятиями годовые отчеты взамен годичных проверок предприятий.

= ...будем вводить порядок выдачи патента на право хозяйствования до выдачи административного разрешения, вместо того чтобы выдавать патент только по получении разрешения; будем внедрять режим публичного информирования через представляемые предприятиями годовые отчеты взамен годичных проверок предприятий.

In Russian, there are two ways to express the future: compound future (that consists of the relevant form of the future tense of быть and the imperfective infinitive) and perfective future (expressed by conjugating a perfective verb). In RVRC, compound future rather than perfective future is used for the former can express a fact in a euphemistic way while the latter is used to express a separate and concrete event in a straight and emphatic way.

In Russian, 6ımb has its modal meaning. Although in Russian grammar, it is regarded as an auxiliary verb in compound future, the hidden 6amb in examples 2-3 equals to will. Palmer (1989) held that will can express modal future, indicating speaker's attitudes towards and opinions on propositions in a statement [48]. Halliday argued that "as for modalization, must ranks the first among modal verbs when it comes to their probability and as for modulation, will ranks lower when it comes to its inclination" [49], i.e., must implies speaker's power and authority while will, speakers' inclination to be equal with listeners. In RVRC, implicit 6 bm latter implies должны (= must). Implicit бымь succeeds in playing the interpersonal role in mediating Chinese government and its people in terms of the following aspects: 1) it helps to show that government shoulders responsibility so as to gain people's approval; 2) it helps listeners (people) to get closer to the speaker (government) emotionally so that both of them have more in common and have more empathy; 3 ) it helps listeners (people) to learn that the intention of the government becomes the promise, i.e., the government is willing and ready to fulfill the obligation. In this way, listeners become more and more confident in the government. Altogether, implicit 6ams in RVRC helps to incorporate government's attitude, responsibility and devotion into the discourse so that a positive and favorable image of government has been created: the government is ready to struggle for people's welfare, to listen to people's appeal and to carry out its duties.

\section{Inter-lingual comparison of aspects in two Reports}

Aspect as an English word emerged in 1835 and derived from Slavic grammar [50]. "After its introduction into Chinese, much research has been done on Chinese verbs and findings show that Chinese can be typologically defined as an aspect prominent language and a Chinese verb always belongs to certain aspect" [51]. In Chinese, there are many devices to mark verb aspects such as “了." (perfective aspect marker), “著” (continuous aspect marker), and “過” (experiential aspect marker). In this research, we take "v+了 1 ” as an example to investigate the distribution of Chinese perfective verbs and their Russian counterparts as shown in Table 3.

Table 3 shows there are 282 “Chinese perfective verb + 了" structures in ST among which 153 were translated into perfective verbs in the past tense and in an indicative mood. Here TT equals to ST in terms of both tense and aspect. 59 were rendered into long passive participles in the past tense with TT being equivalent to ST in aspect but 
some changes in modality; 70 are translated into Russian imperfective verbs in the past tense and in an indicative mood and are equivalent to ST in tense with some changes in aspect.

Table 3. Distribution of "V+了1" and their translation

\begin{tabular}{clcl}
\hline \multicolumn{2}{c}{ ST } & \multicolumn{2}{c}{ TT } \\
\hline \multirow{2}{*}{\}$_{1}$} & \begin{tabular}{l} 
Perfective \\
Indicative mood \\
\cline { 2 - 4 }
\end{tabular} & $\begin{array}{l}\text { Long passive participles } \\
\text { in the past tense }\end{array}$ & $\begin{array}{l}\text { Indicative mood } \\
\text { in the past tense }\end{array}$ \\
\hline 282 & 153 (Sub-group A) & 59 (Sub-group B) & 70 (Sub-group C) \\
\hline
\end{tabular}

Translation in Sub-group A is equivalent to ST in both tense and aspect, which is a common translation practice and is not the concern in our paper. Rather, we focus on the other two sub-groups to find out the hidden ideology reflected in their partial nonequivalence translation.

Although long passive participle (the former) is one of the declensions of a perfective verb, its grammatical and modal meanings differ from those of verbs (the latter) in an indicative mood for the latter denote action, process and results while the former denote features and state; so long passive participles have features and functions of adjectives [52]. For example:

(4) ...分批取消和下放了 416 項行政審批等事項...

(4) ...fēnpī qǔxiāo hé xiàfàng le 416 xiàng xíngzhèng shěnpī děng shìxiàng...

При этом по группам отменено либо передано на исполнение нижестоящим инстанциям 416 предписаний касательно административного визирования.

（5）經過30多年改革開放，我國發展建立了良好的物質基礎和體制條件...

(5) Jīngguò 30 duō nián găigé kāifàng,wǒguó fāzhăn jiànlì le liánghăo de wùzhì jīchǔ hé tǐzhì tiáojiàn...

В результате 30 с лишним лет реформ созданы хорошая материальная база и структурные условия для непрерывного развития.

Results of an event that an adjective modifies tend to be constant, which even become one of the features of the event so that people feel the security and stability of the event for the results are not easy to change. Example 4 is a good case in point for long passive participle "отменено либо передано" makes people feel that the government has delegated the power for government reviews is not a short-term action but will bring long-term welfare to the local or lower-level governments. In this way, the image of China has been created that is far-sighted with stable development.

In addition, the past tense of Russian imperfective verbs can express a concrete process, and implies that the observing time for an action is prior to the time when a speaker utters something or is in parallel to the time when an action is taking place. The observer is also a participant of the event or an agent of the action [38]. Examples 6-7 help illustrate these points: 
（6）嚴厲打擊各類犯罪活動, 強化社會治安綜合治理, 維護了國家安全和公 共安全。

(6) yánlì dăjī gèlèi fànzuì huódòng qiánghuà shèhuì zhiān zōnghé zhilǐwéihù le guójiā ānquán hé gōnggòng ānquán.

Усилилось комплексное наведение общественного порядка, обеспечивалась государственная и общественная безопасность.

（7）在困難和壓力面前, 全國各族人民付出了極大辛勞, 一步一步走了過 來。

(7) zài kùnnán hé yālì miànqián, quánguó gèzú rénmín fùchū le jídà xīn láo, yī bù yỉbù zǒu le guòlái.

Перед лицом этих трудностей и возникшего из-за них прессинга наш многонациональный народ, приложив максимум усилий, шаг за шагом одолел свой путь.

In example 7, “走了過來” was translated into одолел свой путь (imperfective v + complement), which shows readers that the government and its people face pressure together and overcome difficulties together in their tough trip. Such translation has played the following roles: 1 ) it helps to show readers that the government is not only an administrator but also a participant in developing society, struggling for a better life and shouldering responsibility, which helps to bridge the gap between the government and its people and to create a positive government image of transition from an administration-oriented government to a service-oriented one; 2 ) imperfective verb helps to show readers the attitude of the government as a participant, to strengthen the relationship between the government and its people and to show the willingness of the government to communicate with its people equally, thereby creating a populist and flexible government image.

\section{Prosodic studies on high-frequency verbs and their collocates}

As mentioned in Sections four and five, imperfective verbs outnumber perfective ones in the Report. So imperfective verbs are our concern when it comes to prosodic issues. The analysis is made in the theoretical framework of "extended units of meaning" [29-30]. The procedures are:

1) to retrieve high-frequency verbs first and then to extract verbs' prominent collocates in the span of L5-R5 such as direct complements of a verb or subjects of a verb ending with $-\mathrm{cr}^{2}$ in RVRC;

2) to make a statistical analysis of the collocates (usually nouns) of retrieved verbs and figure out the $\mathrm{T}$ value of those nouns [53-54];

3) to retrieve indirect cases of nouns with their $T$ values $\geq 2$;

4) to analyze the semantic inclination of those nouns and generalize their semantic prosodies;

5) to dwell on the semantic inclination of the collocates of high-frequency verbs so as to disclose the government image of China in RVRC.

${ }^{2}$ A Russian verb ending with cя is passive in meaning and its subject is also the object of the action of the verb. 
Data retrieval from RVRC yielded five imperfective verbs with high frequencies: обеспечивать (454), осуществлять (ся) (375), продвигать (ся) (347), стимулировать (283) and ускорять (218). Then we extracted five prominent collocates of each of the five verbs and calculated their collocation frequencies and $\mathrm{T}$ values, as shown in Table 4.

Table 4. Prominent collocates of high-frequency imperfective verbs, frequency and T-values

\begin{tabular}{|c|c|c|c|c|}
\hline Imperfective verbs & Prominent collocates & Frequency & $\begin{array}{c}\text { Frequency } \\
\text { with } \\
\text { node words }^{3}\end{array}$ & T-values \\
\hline \multirow{5}{*}{$\begin{array}{l}\text { Обеспечивать } \\
\text { (454) }\end{array}$} & развитие & 794 & 102 & 9.824 \\
\hline & рост & 356 & 59 & 7.519 \\
\hline & обновление & 187 & 47 & 6.759 \\
\hline & стабильность & 156 & 29 & 5.284 \\
\hline & безопасность & 213 & 25 & 4.851 \\
\hline \multirow{5}{*}{$\begin{array}{l}\text { Осуществлять } \\
\text { (375) }\end{array}$} & достижение & 115 & 55 & 7.372 \\
\hline & инновация & 173 & 77 & 8.817 \\
\hline & праграмма & 431 & 54 & 7.179 \\
\hline & индустриализация & 141 & 31 & 5.494 \\
\hline & надзор & 39 & 10 & 3.127 \\
\hline \multirow{5}{*}{$\begin{array}{l}\text { продвигать(ся) } \\
\text { (347) }\end{array}$} & строительство & 320 & 68 & 8.142 \\
\hline & реформы & 746 & 70 & 8.127 \\
\hline & реконструкцию & 88 & 25 & 4.953 \\
\hline & стабильности & 156 & 34 & 5.759 \\
\hline & интеграция & 58 & 14 & 3.699 \\
\hline \multirow{5}{*}{$\begin{array}{l}\text { Стимулировать } \\
\text { (293) }\end{array}$} & развитие & 794 & 78 & 8.628 \\
\hline & реформа & 746 & 68 & 8.042 \\
\hline & открытость & 187 & 40 & 6.257 \\
\hline & подъём & 49 & 21 & 4.558 \\
\hline & модернизация & 235 & 26 & 4.995 \\
\hline \multirow{5}{*}{$\begin{array}{l}\text { ускорять } \\
\text { (238) }\end{array}$} & развитие & 794 & 59 & 7.491 \\
\hline & строительство & 320 & 43 & 6.468 \\
\hline & реформа & 746 & 40 & 6.107 \\
\hline & реконструкция & 88 & 31 & 5.538 \\
\hline & открытость & 187 & 35 & 5.858 \\
\hline
\end{tabular}

Table 4 shows 25 nouns that are regarded as prominent collocates (with T-values $\geq 2$ ) with node words [49]. "Semantic prosodies can be categorized as positive, neutral and negative ones" [9, p.176]. Among five verbs (node words), обеспечивать and

${ }^{3}$ Here node words are five high-frequency imperfective verbs. 


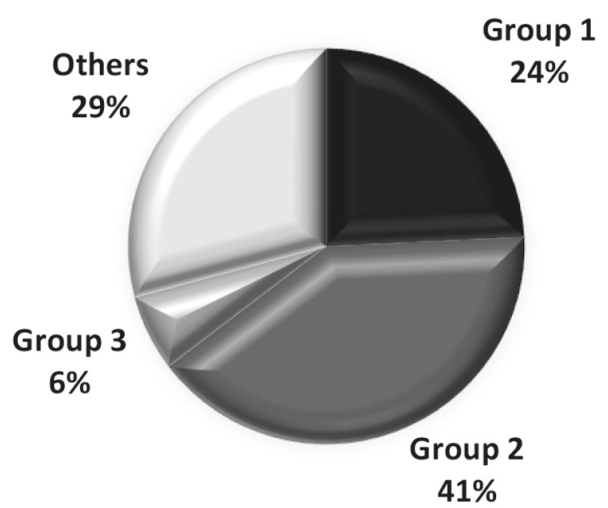

Fig. 2. Distribution of collocates of highfrequency verbs

осуществлять (ся) are neutral while the other three продвигать(ся), стимулировать, ускорять are positive. Twenty-five (tokens, but 17 types) prominent collocates are all about development, reform and construction (concerns of Chinese government). We than sub-categorize them into three groups according to their semantic meanings: Group 1: development and achievement (развитие, подъём, достижение, рост); Group 2: economy building, reform and opening-up (реборма, реконструкиия, инновация, обновление, строительство, модернизаиия, индустриализация, праграмма, открытость); and Group 3: law and social stability (стабильности, безопасность, надзор).

Let's assume that each token of verb corresponds to one collocate in RVRC.In all, there are 1707 collocates with five verbs $(454+375+347+293+238)$ among which Group 1 account for 24\% (414) with Groups 2 and 3 being $41 \%$ (689) and 6\% (106) respectively. And the rest of 1707 are collocates that are sporadically distributed and we label them as "others" (29\%). Figure 2 gives us a clear picture of their distribution:

Figure 2 shows the biggest part is Group 2 in which collocates are all about reform, economy building and reforms at all levels. Here are some examples: Стимулировались развитие образования и его реформа; Продолжала углубляться реформа системы медицины; продвигать социалистическое экономическое, политическое, культурное, социальное и экоцивилизационное строительство. Meanwhile, corresponding verbs are all of positive semantic prosodies, which demonstrates that reform and construction are of the top priority in the eyes of the government. What's more, Chinese government will deepen, promote, strengthen reform and construction in the future. In addition, development is also the key concern of the government for there are many "v + complement" structures involving development (positive prosody) such as обеспечивать устойчивое и здоровое развитие экономики; стимулировать развитие средних и малых банков. Finally, opening-up, law and social stability have also been the key concerns of the government.

Analyses of prominent collocates and " $\mathrm{v}+$ complement" structures in RVRC help to create a positive and favorable image of China: sticking to building economy, implementing the policy of reform and opening-up, safeguarding social stability, strengthening the legal system and focusing on the national economy and people's welfare. From RVRC, Russian readers can feel China's determination to promote its economic development and feel its achievements, which is also the same concern of both the public and sinologists in 
current Russia. "Sinologists in Russia believe that China has been the third largest economy power" [55]. Chinese economy is also one of the key concerns among sinologists and economy researchers in Russia for Chinese economy development has offered new insights for Russian economy (now in transformation). "Russian sinologists also believe that China, after giving up the former USSR developing mode, has been a successful example in improving its economy by great leaps and bounds" [56]. Therefore, compared with Western views, the image of China in Russia is more positive, successful, and pragmatic. Many Russian people hold that Russia should learn from China and draw lessons from China. Such good image of China should be in part attributable to prominent collocates and "v + complement" structures in RVRC.

\section{Conclusions}

The current paper, on the basis of self-compiled parallel corpora of the Report on the Work of the Government (China) (2008-2017), has explored the image of China as it is reflected in the Russian version of the Report from the perspectives of intra-lingual comparison, inter-lingual contrast and distributions of high-frequency Russian verbs (their collocates) and their semantic prosodies. It concludes that Russian version of the Report has projected a positive and successful image of China.

1) More imperfective verbs are used in Russian version of the Report on the Work of the Government (China) than in the Report on the Work of the Government (Russia). The modal meanings of imperfective verbs have projected a positive image of China that is ready to embrace the future with a clear aim and is ready to shoulder the responsibility and to listen to people's appeal;

2) A large number of "perfective verb $+了_{1}$ " structures in ST has been translated into long passive participles and imperfective verbs in TT, two forms whose modal meanings help to present readers with a flexible and populist image of China that is willing to strive with its people for a better future;

3) Certain high-frequency imperfective verbs in RVRC stand out. Semantic prosodies of these verbs and their collocates have revealed the concerns of Chinese government and the image that Chinese government hopes to show to Russian readers; semantic classification of those verbs and collocates shows readers that China is a good and successful example of sticking to building economy and focusing on national welfare and people's livelihood.

\section{References}

1. Fairclough N. Critical Discourse Analysis: The Critical Study of Language. London; New York, Longman, 1995.

2. Fairclough, N., Mulderrig, J., Wodak, R. Critical Discourse Analysis. In: van Dijk, T. A. (ed). Discourse Studies: A Multidisciplinary Introduction. London, Sage, 2011, pp. 537-631.

3. Widdowson H.G. Discourse analysis: a critical view. Language and Literature, 1995a, vol. 4, 3, pp. 157-172.

4. Widdowson H. G. Review of Fairclough: Discourse and Social Change. Applied Linguistics, 1995b, vol. 16, 4, pp. 510-516.

5. Stubbs M. Whorf's children: critical comments on critical discourse analysis: In Ryan, A., Wray A. (Eds). Evolving Models of Language. Clevedon, Multilingual Matters; BAAL, 1997.

6. Toolan M. What is critical discourse analysis and why are people saying such terrible things about it? Language and Literature, 1997, vol. 6, 2, pp. 83-103. 
7. Stubbs M., Gerbig A.Human and inhuman geography: On the computer-assisted analysis of long texts. In: M. Hoey (ed.) Data, Description, Discourse. London, Harper-Collins, 1993, pp. 64-85.

8. Hardt-Mautner G. Only connect critical discourse analysis and corpus linguistics. University of Lancaster. Available at: http://ucrel.Lancs.ac.UK/papers/techpaper/vol 6.pdf. (accessed: 05.06.2019).

9. Stubbs M. Text and corpus analysis: Computer-assisted Studies of Language and Culture. Oxford, Blackwell, 1996.

10. Baker P. A Useful methodological synergy? Combining critical discourse analysis and corpus linguistics to examine discourses of refugees and asylum seekers in the UK press. Discourse and Society, 2008, vol. 3, pp. 273-306.

11. Fairclough N. New Labor, New Language? London, Routledge, 2000.

12. Flowerdew J. Identity politics and Hong Kong's return to Chinese sovereignty: analyzing the discourse of Hong Kong's first chief executive. Journal of Pragmatics, 2004, vol. 9, pp. 1551-1578.

13. Orpin D. Corpus linguistics and critical discourse analysis: examining the ideology of sleaze. International Journal of Corpus Linguistics, 2005, vol. 10, 3, pp. 7-61.

14. Partington A. The Linguistics of Political Argument: The Spin-doctor and the Wolf-pack at the White House. London; New York, Routledge, 2003.

15. Vessey R. Corpus Approaches to Language Ideology. Applied Linguistics, 2017, vol. 38, 3, pp. $277-$ 296.

16. Xu Jun. Fanyilun [On Translation]. Wuhan, Hubei jiaoyu chubanshe, 2003. 215 p. (In Chinese)

17. Lefevere A. Translation, Rewriting and Manipulation of Literary Fame. London; New York, Routledge, $1992.8 \mathrm{p}$.

18. Zhuang Rou-yu. Lun duoyuan xitong lilun yanjiu fanyi de yishi xingtai de juxian [Limitations of translation ideology research from the perspective of polysystem theory]. Translation Quarterly, 2000, vol. 16, 17. 123 p. (In Chinese)

19. Chen De-hong, Zhang Nan-feng. Xifang fanyi lilun jingxuan [Selected Readings of Western Translation Theories]. Hongkong, Xianggang chengshi daxue chubanshe, 2000. (In Chinese)

20. Hu Kai-bao, Li Xiao-qian. Yuliaoku piping yixue [Corpus-based critical translation studies: Connotations and implications]. Zhongguo waiyu, 2015, vol. 1, pp. 90-100. (In Chinese)

21. Stubbs M., Gerbig A. Human and inhuman geography: On the computer-assisted analysis of long texts. In: M. Hoey (ed.) Data, Description, Discourse. London, Harper-Collins, 1993, pp. 64-85.

22. Tang Li-ping. Yuliaoku yuyanxue zai piping huayu fenxi zhong de zuowei kongjian [The potentials of corpus linguistics in strengthening critical discourse analysis]. Waiguoyu. 2011, vol. 4, pp. 43-49. (In Chinese)

23. Guo Song. Jiyu yuliaoku de piping huayu fenxi [Corpus-based critical discourse analysis]. Tianjin waiguoyu daxue xuebao, 2011, vol. 8, pp. 12-17. (In Chinese)

24. Zhang Shu-jing. Yuliaoku zai piping huayu fenxi zhong de zuoyong [The application of corpus to critical discourse analysis]. Zhengzhou daxue xuebao, 2014, vol. 3, pp. 130-133. (In Chinese)

25. Zhu Xiao-min. Piping huayu fenxi shijiaoxia de "Zhengfu gongzuo baogao" yingyi yanjiu — jiyu yuliaoku de diyi rencheng daici fushu kaocha [Corpus-based critical discourse analysis of English version of the Report on the Work of Government-with a case of first pronoun plural]. Waiyu yanjiu, 2011, vol. 2, pp. 73-79. (In Chinese)

26. Tang Li-ping. Meiguo dabaozhi zhongguo xingxiang de yuliaoku yuyanxue fangfa fuzhuxia de piping huayu fenxi [Corpus-Based Critical Discourse Analysis of China Image in the US Prestigious Newspaper]. Beijing, Gaodeng jiaoyu chubanshe, 2016, pp. 43-49. (In Chinese)

27. Qian Yu-fang, Tian Hai-long. Huayu yu zhongguo shehui bianqian: yi zhengfu gongzuo baogao weili [Discourse and social changes in China with a case of the Report on the Work of the Government]. Waiyu yu waiyu jiaoxue, 2011, vol. 3, pp. 40-43. (In Chinese)

28. Shao Bin, Hui Zhi-ming. Xifang meiti shiyeli de "zhongguomeng" - yixiang jiyu yuliaoku de piping huayu fenxi [Corpus-based critical discourse analysis of China Dream in the western media]. Waiyu yanjiu, 2014, vol. 6, pp. 28-33. (In Chinese)

29. Sinclair J. New evidence, new priorities, new attitudes. In: Sinclair, J. (ed). How to Use Corpora in Language Teaching. Amsterdam, John Benjamins, 2004, pp. 271-299.

30. Sinclair J., Carter R. Trust the Text: Language Corpus and Discourse. London, Routledge, 2004. 
31. Hu Jiang. Yiyi danwei yu piping huayu fenxi — jiyu yuliaoku de xifang meiti shehua junshi baodao yishi xingtai fenxi [Meaning units and critical discourse analysis: Corpus-based study on China-related military report in the Western media]. Jiefangjun waiguoyu xueyuan xuebao, 2016, vol. 5, pp. 73-81. (In Chinese)

32. Bondarko A. V. Theory on Functional Grammar, Tense, Aspect and Mood. Leningrad, Nauka Publ., 1990. (In Russian)

33. Shelyakin M. A. Connection between Mood and Aspect. Teoriya funkcional'noi grammatiki. Temporal'nost'. Modal'nost'. Leningrad, Nauka Publ., 1990, pp. 110-122. (In Russian)

34. Wang Li. Zhongguo xiandai yufa [Modern Chinese Grammar]. Beijing, Shangwu yinshuguan, 1943/1985. (In Chinese)

35. Lü Shu-xiang. Zhongguo wenfa yaolue [A Gist of Chinese Grammar]. Beijing, Shangwu yinshuguan, 1944; 1982. (In Chinese)

36. Gao Ming-kai. Hanyu yufalun [Chinese Grammar]. Beijing, Shangwu yinshuguan, 1948; 2011. (In Chinese)

37. Dai Yao-jing. Xiandai huanyu shiti yanjiu [Tense and Aspect Systems in Modern Chinese]. Hangzhou, Zhejiang jiaoyu chubanshe, 1997. (In Chinese)

38. Zhang Jia-hua. Xiandai eyu tixue [Modern Russian Stylistics]. Beijing, Gaodeng jiaoyu chubanshe, 2004. (In Chinese)

39. Yang Ming-tian. Dongci biaoda de zhuguan qingtai yiyi [Subjective and modal meanings embodied in Russian verbs]. Zhongguo eyu jiaoxue, 2000, vol. 4, pp. 32-37. (In Chinese)

40. Deng Ying. Shilun eyu tifanchou de zhuguanxing jiqi dui eyu jiaoxue de qishi [Subjectivity of Russian verb aspects and implications for Russian teaching]. Waiyu yanjiu, 2011, vol. 2, pp. 46-51. (In Chinese)

41. Af Lukin. Eguoxiang kan zhongguolong: 17-20 shiji zhongguo zai eluosi de xingxiang [China (17 $7^{\text {th }}$ $20^{\text {th }}$ centuries) in the Eyes of Russian]. Chongqin, Chongqing chubanshe, 2007. (In Chinese)

42. Li Sui-an. Zhongguo yu eluosi: guojia xingxiang zhi bijiao [A comparative study on country image of China and Russia]. Xiboliya yanjiu, 2007, vol. 4, pp. 53-55. (In Chinese)

43. Qiang Xiao-yun. Shilun guoji yimin yu guojia xingxiang de guanlianxing - yi zhongguo zai eluosi de guojia xingxiang weili de yanjiu [Correlation between international immigrants and country image with a case of China image in the eyes of Russian]. Shehui kexue, 2008, vol. 7, pp. 62-68. (In Chinese)

44. Sun Fang. Eluosi de zhongguo xingxiang [China Image in Russia]. Beijing, Renmin chubanshe, 2010. (In Chinese)

45. Li Wei. Eluosi yanzhong de zhongguo - yingxiang zai e zhongguo xingxiang de wenhua yinsu fenxi [Cultural factors affecting the image of China in the eyes of Russian]. Guowai shehui kexue, 2011, vol. 1, pp. 91-96. (In Chinese)

46. Shen Ying, Wu Gang. Eluosi quyu meiti zhong de zhongguo xingxiang - yi "zhoubao", "shiyejie", "wulaer zhengzhiwang" baodao weili [China image in Russian media with cases of State Newspaper, Entrepreneurship and Ural Politics Web]. Eluosi dongou zhongya yanjiu, 2013, vol. 1, pp. 17-22. (In Chinese)

47. Zhu Jing-tao, Shi Ya-jun. Eluosi shehui yulun zhong zhongguo xingxiang renzhi de "erlv beipan" yi jinnian e shehua mindiao wei kaocha wenben [Antinomies in understanding China image in Russian media with cases of China-related survey in Russia]. Wuhan daxue xuebao (zhexue shehui kexueban), 2015, vol. 1, pp. 103-108. (In Chinese)

48. Palmer F. The English Verb. London, Longman, 1989.

49. Halliday M.A.K. An Introduction to Functional Grammar. London, Arnold, 1994; 2000, pp. 88-91.

50. Chen Qian-rui. Dangdai timao lilun yu hanyu sicengji de timao xitong [On the Aspectual Theories and the Four-level Chinese Aspectual System]. Xanyu xuebao, 2005, vol. 3, pp. 20-28. (In Chinese)

51. Shang Xin. Yinghan ti fanchou duibi yanjiu [A Contrastive Study on English and Chinese Aspectual Categories]. Shanghai, Shanghai renmin chubanshe, 2007. (In Chinese)

52. Wang Ya-min. Hanyu dongtai xingrongci yu eyu xingdongci bijiao yanjiu [Contrastive Study on Dynamic Adjectives in Chinese and Adjective Verbs in Russian]. Xibei shida xuebao (shehui kexueban), 1997, vol. 3, pp. 103-106. (In Chinese)

53. Wei Nai-xing. Yuyi yun yanjiu de yiban fangfa [Approaches to studying semantic prosodies. Foreign]. Waiyu jiaoxue yu yanjiu, 2002, vol. 4, pp. 300-307. (In Chinese) 
54. Tao Yuan, Hu Gu-ming. Zhishi dongci yuyi yun fanyi yanjiu - jiyu ehan pingxiang yuliaolu de zhuanye wenben [Research on Semantic Prosody of Causative Verbs in Academic Texts from RussianChinese Parallel Corpora]. Wuhan daxue xuebao, 2015, vol. 1, pp. 119-124. (In Chinese)

55. Vasyukhin O.V., He W. Economic Development in China. Problemy i perspektivy ekonomiki i upravleniia: materialy III Mezhdunar. nauch. konf. St. Petersburg, Zanevskaya Square Publ., 2014, pp. 230231. (In Russian)

56. Zhiguleva V.V. From plan to market, the PRC experience in the reform of the pricing system (19782005). Moscow, Publishing house RAS, 2006. (In Russian)

Received: December 26, 2019 Accepted: March 17, 2020

Author's information:

Yuan Tao - Dr. Sci. in Philology; tao1973@mail.ru

\title{
Критический анализ дискурса образа Китая в отчете о работе правительства на примере видов глагола русского языка
}

\author{
Юань Тао \\ Шэньсийский педагогический университет, \\ Китайская Народная Республика, 710062, Сиань, ул. Чангань (Юг), 199
}

Для цитирования: Yuan Tao. Critical Discourse Analysis of the Image of China in the Russian Version of the Report on the Work of the Government with a Case of Russian Verb Aspects // Вестник Санкт-Петербургского университета. Востоковедение и африканистика. 2020. Т. 12. Вып. 2. C. 178-193. https://doi.org/10.21638/spbu13.2020.202

Статья посвящена исследованию языкового образа правительства Китая. Теоретическая основа работы - критический анализ дискурса, а предмет - вид глаголов. В русском языке это важная грамматическая категория, согласно которой выделяются глаголы совершенного и несовершенного вида. На основе «Отчета о работе правительства Китая (2008-2017)» на китайском и русском языке и «Отчета о работе правительства России (2008-2017 гг.)» в работе проводится внутриязыковой и межъязыковой анализ образа правительства Китая. Исследуется, как на русском языке в обоих источниках создается образ Китая путем использования двух видов глаголов, их модального значения и межличностных функций. В «Отчете правительства Китая» на русском языке анализ структур «V + 了 1 », переданных как пассивные причастия или глаголы несовершенного вида, позволил выявить идеологические аспекты в переводе. В последнее десятилетие в риторике представителей китайского правительства часто встречаются сочетания глаголов несовершенного вида. Мы разделили эти глаголы на три типа, высчитали их частотность. После этого мы пришли к выводу, что образ правительства Китая в переводных текстах «Отчета о работе правительства Китая (2008-2017)» является популистским и относительно гибким. Кроме того, можно также сказать, что правительство Китая ответственно относится к вопросу национального благосостояния народа.

Ключевые слова: критический анализ дискурса, вид глагола, модальность, образ языка.

Статья поступила в редакцию 26 декабря 2019 г. Статья рекомендована в печать 17 марта 2020 г.

Контактная информация:

Юань Тао - д-р филол. наук; tao1973@mail.ru 